\title{
URBAN GREEN AREAS AND WOODY PLANT COMPOSITION: DWELLING SPACE QUALITY FACTOR IN THE KLOKOČINA HOUSING ESTATE
}

\author{
MÁRIA BIHUŇOVÁ ${ }^{1}$, JÁN SUPUKA $\otimes^{1}$, ATTILA TÓTH ${ }^{1}$, KAROL ŠINKA $^{2}$, GABRIEL KUCZMAN ${ }^{1}$ \\ ${ }^{1}$ Department of Garden and Landscape Architecture, Faculty of Horticulture and Landscape Engineering, Slovak University of Agriculture in Nitra, Tr. A. \\ Hlinku 2, 94976 Nitra, Slovak Republic; e-mail: jan.supuka@uniag.sk, maria.bihunova@uniag.sk, attila.toth@uniag.sk, gabriel.kuczman@uniag.sk \\ ${ }^{2}$ Department of Landscape Planning and Land Consolidation, Faculty of Horticulture and Landscape Engineering, Slovak University of Agriculture in Nitra, \\ Tr. A. Hlinku 2, 94976 Nitra, Slovak Republic; e-mail: karol.sinka@uniag.sk \\ $\triangle$ Corresponding author
}

Received: 10 January 2020 / Accepted: 19 February 2020

Abstract

Bihuňová M., Supuka J., Tóth A., Šinka K., Kuczman G.: Urban green areas and woody plant composition: Dwelling space quality factor in the Klokočina housing estate. Ekológia (Bratislava), Vol. 40, No. 1, p. 80-90, 2021.

\begin{abstract}
The environment of a city is influenced by global and local climate changes, pollution load from transport, industry and local heat sources. Green spaces as part of the urban green infrastructure fulfil multiple ecosystem services and improve the environmental and residential quality of a city. The level of positive effects of green spaces depends on their area, distribution within the city and the proportion of trees. The aim of the paper was to evaluate land cover structure in a selected segment of the housing estate Klokočina in Nitra, Slovakia. The evaluation focused on the share of biologically active and inactive surfaces, as well as the parameters of woody plant structure in green spaces. Green areas account for $58.70 \%$, while built-up areas, parking lots and roads cover in total $41.30 \%$. Biologically inactive anthropogenic horizontal and of building envelope areas represent $67.30 \%$. Biologically active green areas represent $32.70 \%$. The share of areas with tree crown overlap on horizontal areas is $20.82 \%$, other areas are paved surfaces or grassland. We calculated the indices of the quality of green spaces from the individual categories of areas: proportional green area index (PGAI), effective green area index (EGAI) and tree shade index (TSI). The tree species composition consists of 36 deciduous and 11 coniferous tree species, and 20 shrub species. We evaluated the biometric traits of trees as the tree height, crown width, stem girth and tree vitality class (TVC). The correlations between tree traits were statistically tested with a significant result. In the group of biologically active areas of greenery, we propose to increase the proportion of trees, to establish more natural lawns and xerophyte flower beds. In the category of inactive areas, we propose the reconstruction of parking lots to grass paved surfaces.
\end{abstract}

Key words: town structure, housing estate, land cover, green spaces, tree quality traits.

\section{Introduction}

Currently, $50 \%$ of the world population lives in cities. In Europe's most urbanised regions, this number increases up to $73 \%$ and it is expected that two-thirds of the world population will live in cities by 2050 . The enormous growth of cities is causing complex environmental problems, such as air pollution and climate change, both global and local warming. Great hope is placed in urban vegetation, which through ecosystem services of green infrastructure has a significant potential for mitigating these negative phenomena (Yong, 2010; Bihuňová et al., 2017; Tóth, Timpe, 2017; Vaculová, Štěpánková, 2017). Urban vegetation has recently been defined as urban green spaces (UGS), urban green areas (UGA), or urban green infrastructure (UGI). In addition to these definitions, in more than 120 journals' scientific articles, other similar definitions have been published that take into account scientific disciplines and categories of ecosystem services (Supuka, 1996; Taylor, Hochuli, 2017). The most environmentally and ecologically effective components are woody plants and predominantly trees, as elements of persistent and spatially dimensional compositions. Biological processes of phytomass cause the storage of carbon as well as other gaseous components from the atmosphere of cities (McHale et al., 2009; Timilsina et al., 2014). At the same time, they increase the share of biogenic volatile substances beneficial to the quality of living environment and useful for human health. A wide range of components from anthropogenic activity are emitted into the atmosphere, six of which are the main indicators based on human health and environmental quality, namely: $\mathrm{CO}_{2}, \mathrm{O}_{3}, \mathrm{NO}_{2}, \mathrm{SO}_{2}, \mathrm{~Pb}, \mathrm{PM}_{10}$ and $\mathrm{PM}_{25}$ (Jayasooriya et al., 2017). Using the i-Tree Eco software, the air cleaning capacity of tree vegetation with an area of 1000 $\mathrm{m}^{2}$ (0.1 ha) was calculated at the following values: $68 \mathrm{~kg} \mathrm{NO}, 22$ $\mathrm{kg} \mathrm{SO}_{2}, 9 \mathrm{~kg} \mathrm{CO}, 260 \mathrm{~kg} \mathrm{O}_{3}, 225 \mathrm{~kg} \mathrm{PM}_{10}$ and $7 \mathrm{~kg} \mathrm{PM}{ }_{25}$ annually (Nowak et al., 2006; Jayasooriya et al., 2017). In the example of 15 cities in Canada, the value of pollution removal by urban tree vegetation is 16,500 tonnes on an average (2.14-5.38 g.m $\mathrm{m}^{-2}$. year $^{-1}$ ) in 2010, which is also expressed in terms of health effect per inhabitant. The monetary value ranges from 16.2 to $31.4 \mathrm{mil}$. USD per year. (Nowak et al., 2013, 2018). Similar research results have been achieved in Strasbourg with pollutant absorption ef- 


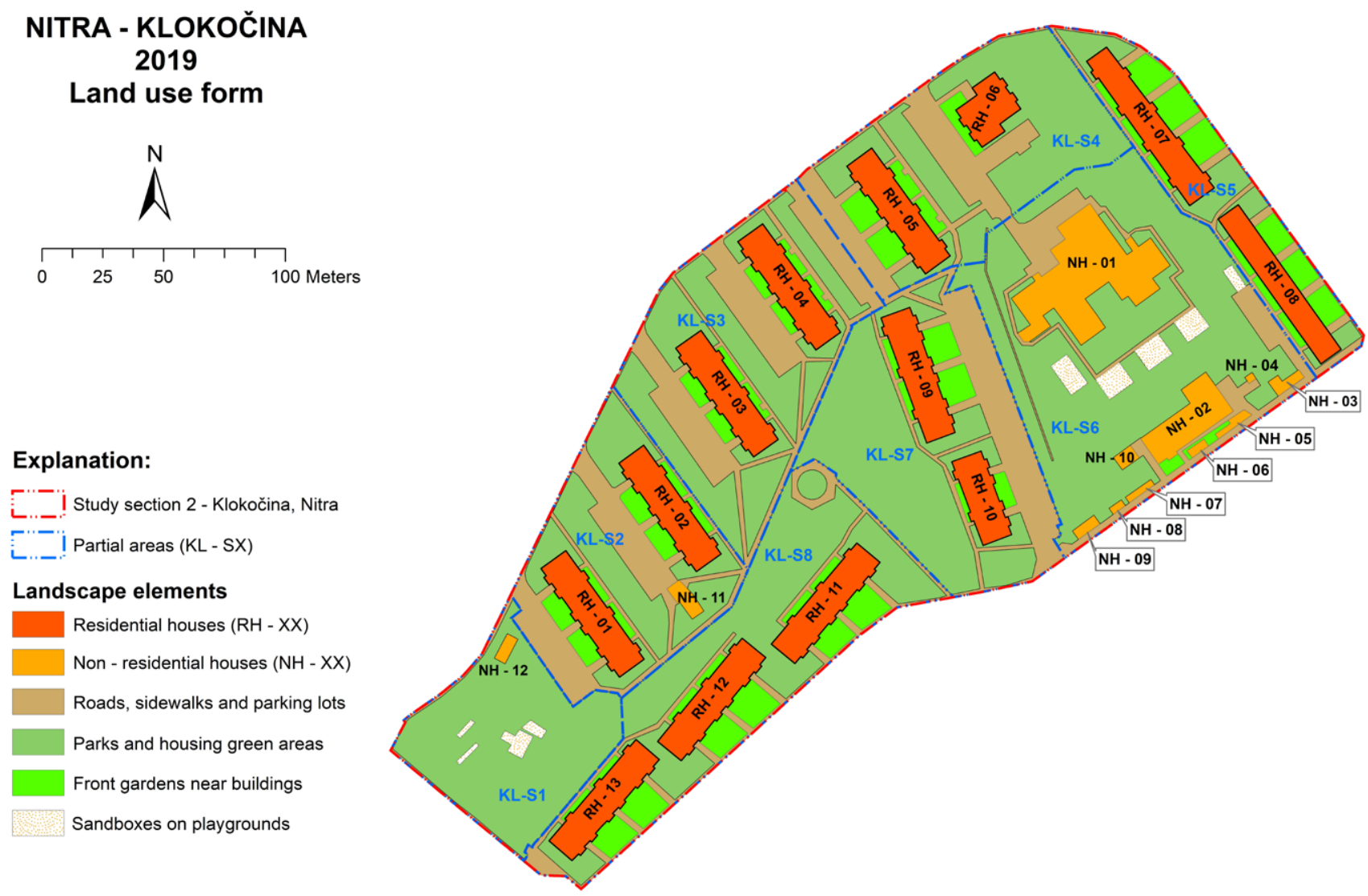

Fig. 1. Land use form in Klokočina housing estate segment (Elaborated: Šinka, Supuka, 2019).

fect through public green spaces of an average of 88.33 tonnes per year (Selmi et al., 2016). The city's average temperatures are higher by +1 to $+3{ }^{\circ} \mathrm{C}$ compared to the neighbour country, making the city's territory as urban heat island (UHI) (Yang et al., 2016). Differences depend on meteorological conditions (wind, humidity, radiation, precipitation, growing season, time of day) and physical aspects of urban structure (land use, morphology, construction materials, urban vegetation share, altitude and longitude of city position, etc.) (Martin et al., 2015). The cooling effect of urban vegetation is based on evaporation and transpiration, but also on the shading effect of tree crowns (Kong et al., 2014). The cooling and climate mitigation effect was dependent on the size, shape and layout of parkland and other green areas in Göteborg, Sweden, where a small park of 3 hectares had a cooling effect of $1.7^{\circ} \mathrm{C}$ and a large park of 15 ha to $5.9^{\circ} \mathrm{C}$ (Eliasson, Upmanis, 2000). Similarly, at the Athens industrial/commercial area Eleonas, a cooling effect was found between a large city park and an adjacent area of more than $5^{\circ} \mathrm{C}$, where a cooling effect from 0.5 to $1.2^{\circ} \mathrm{C}$ was identified up to $2.8 \mathrm{~km}$ from the rated park (Papangelis et al., 2012). Other studies confirm the cooling effect by green spaces from 0.94 to $1.15^{\circ} \mathrm{C}$ for distances up to 500 $\mathrm{m}$ (Bowler et al., 2010). Surface temperatures in Fuzhou, China's parks, were measured to be $4-8{ }^{\circ} \mathrm{C}$ lower than the non-green areas and green spaces greater than 10 ha have a good cooling effect (Yu et al., 2018). The cooling effect of green spaces have area limits, as Chen et al. (2009) showed that a 5 ha of green space is a threshold value for cooling, and green spaces greater than 5.6 ha have a positive cooling effect and an area exceeding 20 ha will not increase the cooling effect (Jaganmohan et al., 2016). The study in the city of Poznan, Poland presented that coniferous canopy contributes less to the reduction of surface temperature than deciduous forest, where the reason for this is lower albedo of coniferous trees (Majkowska et al., 2017). When evaluating surface temperature and relative air humidity in Nitra, Slovakia, it was found that the cooling effect is dependent on the canopy shape and tree crown cover and reaches from 0.55 to $1.83{ }^{\circ} \mathrm{C}$ as compared to a street without green elements (Klein, Rózová, 2017). From the category of support services, many publications emphasize the development and maintenance of biodiversity, for example, amphibians, birds, mammals, insects (Goddard et al., 2010; Niemelä, 2014). Green areas have city scape importance, promote human health and well-being, and provide space for recreation, culture and aesthetics for city dwellers (Shackleton et al., 2015; Vallecillo et al., 2018). The wide range of ecosystem services of green spaces in urban structure depend on the quantity and quality of green infrastructure elements and their 
Table 1. Description of tree vitality parameter classes according to crown shape and tree foliage indicators.

\begin{tabular}{|c|l|l|}
\hline Tree vitality class & Crown shape & Tree foliage \\
\hline 5 & Well-developed regular crown $\geq 75 \%$ tree height & No to slight foliage loss $\leq 10 \%$ \\
\hline 4 & Slightly reduced crown $51-74 \%$ & Slight foliage loss $11-25 \%$ \\
\hline 3 & Moderate reduced crown $26-50 \%$ & Moderate foliage loss $26-50 \%$ \\
\hline 2 & Heavily reduced crown $11-25 \%$ & Strong foliage loss $51-75 \%$ \\
\hline 1 & Crown dying $\leq 10 \%$ & Very strong foliage loss $\geq 75 \%$ \\
\hline
\end{tabular}

distribution within the city. For the territory of Warsaw, Poland, the so-called ratio of biological vital areas (RBVA) has been described, which represents all green and blue areas compared to the built-up areas of the city. The authors consider the value of 41.7 to $48.0 \%$ to be the optimal limit of RBVA in terms of thermal and hydrological effect in the city (Szulczewska et al., 2014). In Strasbourg, France, similar studies have been carried out that report a $54.07 \%$ share of green areas as optimal, where their fragmentation, shape, size and distribution within the city are significant (Selmi et al., 2016). In green spaces, the decisive proportion of tree cover in relation to grassland is very significant (Lee et al., 2016; Vallecillo et al., 2018). In the structure of the tree component, the tree canopy, age and height of trees, crown volume and species composition are decisive (Tian et al., 2014), but also the crown structure, texture and density are very important (Yan, Yang, 2017). The share of trees in green spaces is expressed as a shade tree factor (McPherson et al., 2018). The ratio of anthropogenic reinforced to biologically active surfaces is often defined as the green factor (GF) (Juhola, 2018). In green spaces establishment, it is also important to select suitable tree species that meet the conditions of resilience to changed urban environment, but also the criteria of growth sociability (invasive manifestation), health risk (allergens), resistance to diseases and pests and so on (Saebo et al., 2005). The quality and suitability of woody plant species for urban environment is most often assessed using visual growth, ecological, physiological or genetic markers (Uhrin et al., 2018).

The aim of this study is to: (1) evaluate the structure of land cover in a chosen housing estate in Nitra; (2) evaluate the structure of biologically active areas of green spaces and areas of technical and construction objects; (3) evaluate areas at the share of comparative factors; (4) evaluate woody plant composition in terms of species diversity; (5) assess the biometric traits of the tree species and their statistical correlations.

\section{Material and methods}

\section{Study site}

For the purposes of this study, we chose the city of Nita, Slovakia, which has a total of 80 thousand inhabitants. The assessed part of the city is represented by the residential zone of three neighbour housing estates, namely Klokočina, Diely and Čermáň, where a total of 31,800 inhabitants live. For the purposes of the research, the Klokočina housing estate was chosen, where 23,000 people live in block houses. The housing estate was founded and gradually built since 1970 with an average of 10-12 floors and a popu- lation density of 300 inhabitants per 1 ha on average (according to the statistical database - the city of Nitra, 2018). The green spaces in the three neighbour housing estates Klokočina, Diely and Čermán together represent an area of 180 ha. At the examined Klokočina housing estate, the green areas represent a total of 56.2 ha with a share of $22.7 \mathrm{~m}^{2}$ per inhabitant (Supuka et al., 2019). For a detailed evaluation of the coverage of functional areas and the assessment of greenery parameters, a segment of this housing estate on an area of 6.44 ha was selected, the boundary of which is defined by the road network (Fig. 1).

\section{Evaluation of land cover and vegetation structure}

The land cover was evaluated using an ortho photomap and a vectorised cadastral map both from 2018 (NLC Zvolen). The horizontal land-use and vertical construction areas were calculated using Arc GIS Desktop software using spatial vector data. From the characteristics of green areas, quantitative parameters were evaluated by sectors and in aggregate (Figs. 1, 2, Table 2): total green area, shade tree crown cover, shrubby cover area and open grass cover area. Horizontal areas of abiotic elements and paved areas are roads, walkways, parking lots and built-up areas. In addition, the area of vertical walls plus roofs was measured. The following relative indices were calculated from the measured characteristics:

- Proportional green area index (PGAI), as the share of green area cover (GAC) to built-up area cover (BAC),

- Effective green area index (EGAI), as the proportion of green area cover (GAC) to biologically all inactive surfaces (BISC),

- Tree shade index (TSI), as the proportion of tree area cover (TAC) to all horizontal area with tree cover share (HAC),

- Anthropological level of woody plant species (ALPS), as a proportion of alien woody plant species number (APS), to the total (alien plus natural) woody plant species number (TPS) (Supuka et al., 2013).

\section{Evaluation of tree characteristics and parameters}

In the green spaces, each tree was assessed using biometric attributes such as species, trunk circumference, tree height, crown width, approximate age, height, crown width and crown height. The qualitative assessment of the trees was performed using qualitative features of the crown such as density, health, and pest and disease damage. The identified qualitative traits of the crown were expressed by tree crown vitality classes (according to Hrubík et al., 2011 and modified by Uhrin, Supuka, 2016) (Table 1). 


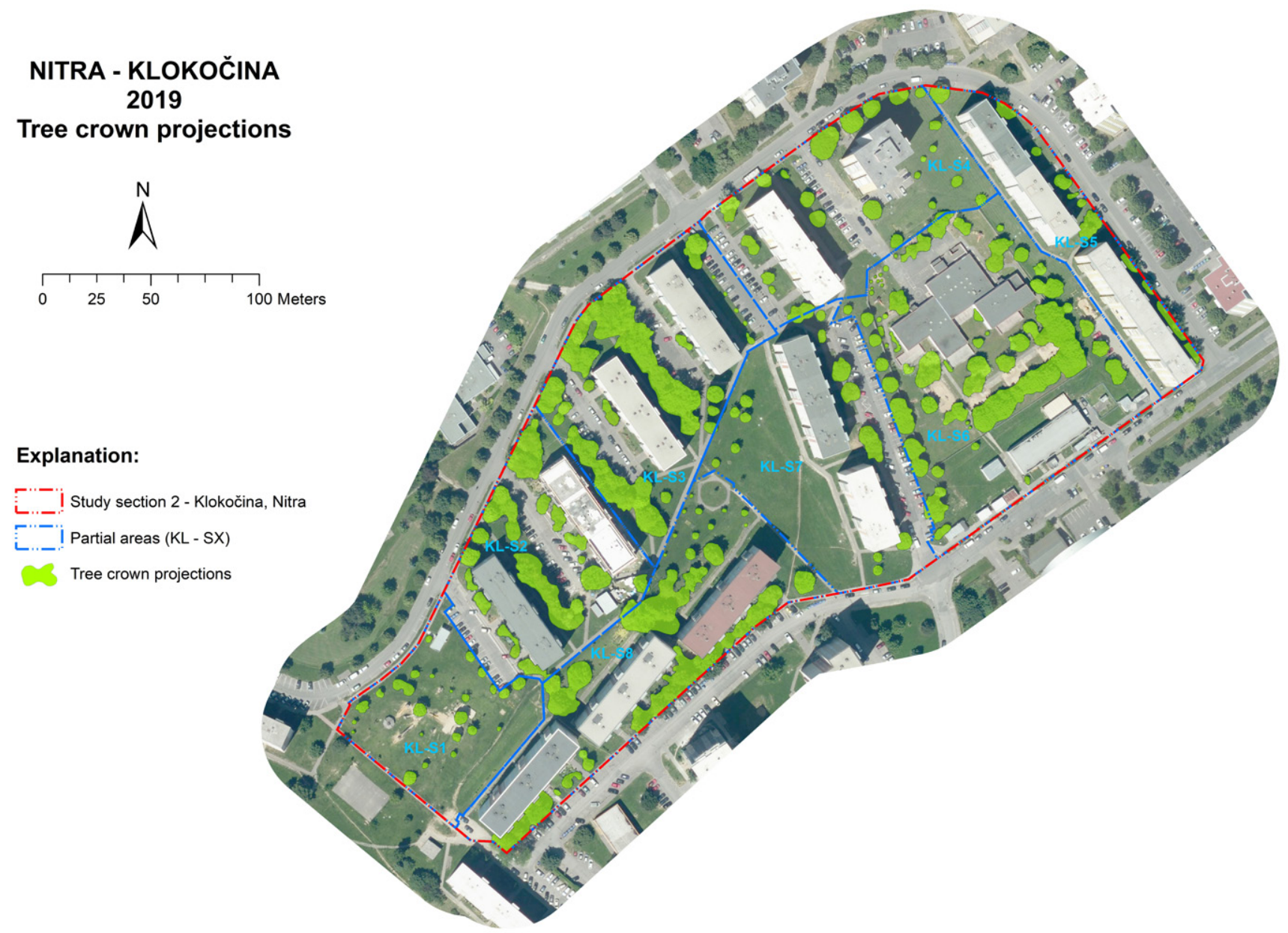

Fig. 2. Tree crown projection in Klokočina housing estate segment (Elaborated: Šinka, Supuka, 2019).

\section{Statistical analyses}

The whole set of trees in the Klokočina study area consists of 71 coniferous trees and 222 deciduous trees. Many species were represented only in a small number of individuals. Species with fewer than 10 individuals were excluded from the statistical analysis. Four coniferous species (Picea abies L. Karst., P. pungens Engelm., Pinus nigra Arnold.) and seven deciduous tree species (Acer platanoides L., A. pseudoplatanus L., Betula pendula Roth., Fraxinus excelsior L., Tilia cordata L., T. platyphyllos Scop., T. tomentosa Moench.) were included in the statistical analysis. Basic statistical analysis and cross correlation were performed in traits of tree height, stem girth, crown width and vitality class, mainly in the coniferous and deciduous tree species. Kendall's Tau-b correlation coefficient was used to express correlation between trees. For the analysis of variance, nonparametric one-way ANNOVA was used and the differences between class of vitality parameter in traits were tested by Kruskal-Wallis test and median one-way analysis. The influence of tree height, stem girth and crown width on tree vitality parameter was found by generalized linear model. All analyses were carried out using SAS Enterprise Guide 7.1. (SAS Institute Inc., 2008).

\section{Results}

The analysis of the spatial orthophotomap and the vectorised cadastral map were used to calculate the areas of landscape components, respectively land cover, for the defined sector of the Klokočina housing estate (Fig. 1, Table 2). In the group of builtup areas, we included residential and non-residential buildings, the total area of which is $11,836.47 \mathrm{~m}^{2}$, which is $18.38 \%$ of the total area of the housing estate. The relatively high area is represented by road networks (roads and paved surfaces) and parking lots. A small proportion is represented by sandpits in children's playgrounds. Biologically inactive anthropogenic surfaces make up a total of $25,595.93 \mathrm{~m}^{2}$, which is $41.30 \%$ of the housing estate area. Biologically active areas consist of inter-block residential greenery and front gardens of residential blocks, together $37,804.17 \mathrm{~m}^{2}$, which is $58.70 \%$ of the area of the estate. We consider such representation of green areas in the area of the assessed housing estate to be a balanced to optimal status in relation to the hard paved surfaces. Car parks account for the highest proportion of up to $80 \%$ of all paved surfaces (Fig. 1). The surface of the car parks is $100 \%$ asphalt (tar). In terms of civic amenities for the residents of housing estates, parking areas are needed, 
Table 2. Share of areas in the Klokočina housing estate.

\begin{tabular}{|c|c|c|c|c|}
\hline \multirow[b]{2}{*}{ Landscape component } & \multicolumn{2}{|c|}{ Land use cover } & \multicolumn{2}{|c|}{ Tree cover projection } \\
\hline & Area in $\mathbf{m}^{2}(\mathbf{h a})$ & Share in \% & Area in $\mathbf{m}^{2}$ (ha) & $\begin{array}{c}\text { Share in \% of land } \\
\text { cover }\end{array}$ \\
\hline Residential houses & $\begin{array}{c}9063.15 \\
(0.906 \mathrm{ha})\end{array}$ & 14.07 & - & - \\
\hline Non-residential houses & $\begin{array}{c}2773.32 \\
(0.277 \mathrm{ha}) \\
\end{array}$ & 4.31 & $\begin{array}{c}39.24 \\
(0.004 \mathrm{ha})\end{array}$ & 1.41 \\
\hline Children sandboxes & $\begin{array}{c}667.37 \\
(0.067 \mathrm{ha})\end{array}$ & 1.04 & $\begin{array}{c}165.48 \\
(0.016 \mathrm{ha})\end{array}$ & 24.79 \\
\hline Roads, parking lots and footpaths & $\begin{array}{l}14092.09 \\
(1.41 \mathrm{ha})\end{array}$ & 21.88 & $\begin{array}{c}1688.00 \\
(0.169 \mathrm{ha})\end{array}$ & 11.98 \\
\hline $\begin{array}{l}\text { Parks, inter-block and street } \\
\text { greenery }\end{array}$ & $\begin{array}{l}32546.67 \\
(3.255 \mathrm{ha})\end{array}$ & 50.54 & $\begin{array}{c}8455.32 \\
(0.846 \text { ha }) \\
\end{array}$ & 25.97 \\
\hline Front gardens near buildings & $\begin{array}{l}5257.50 \\
(0.526 \mathrm{ha}) \\
\end{array}$ & 8.16 & $\begin{array}{l}1175.74 \\
(0.118 \mathrm{ha})\end{array}$ & 22.36 \\
\hline Total & $\begin{array}{l}64400.10 \\
(6.44 \mathrm{ha})\end{array}$ & 100.00 & $\begin{array}{c}11523.78 \\
(1.152 \mathrm{ha})\end{array}$ & $\begin{array}{c}20.82 \\
\text { In average }\end{array}$ \\
\hline Landscape component & \multicolumn{4}{|c|}{ Building envelop area in $\mathbf{m}^{2}$ (ha) } \\
\hline $\begin{array}{l}\text { Residential houses } \\
\text { (RH 01- RH 13) }\end{array}$ & \multicolumn{4}{|c|}{55965.09 (5.6 ha) } \\
\hline $\begin{array}{l}\text { Non-residential houses } \\
\text { (NH 01-NH 12) }\end{array}$ & \multicolumn{4}{|c|}{7080.90 (0.71 ha) } \\
\hline
\end{tabular}

also due to the high degree of car mobility of residents of the housing estate. The potential to increase the biologically active areas of greenery can be achieved by building parking houses, or by reconstructing and converting asphalt car parks into grassed paved areas. These will also function as permeable surfaces for the retention and penetration of rainwater into the soil.

In the next part of the paper, we evaluate the total nonbiologically inactive area of surfaces, which consist of horizontal built-up areas and the area of the housing of residential buildings, designated as RH01-RH13. Residential houses are 20.2-25.7 $\mathrm{m}$ high and consist of 7-8 residential floors. Only one residential building reaches $40.6 \mathrm{~m}$ and consists of 13 residential floors. Non-residential buildings are civic amenities and kindergarten, marked as NH01-NH12. They reach an average height of $4 \mathrm{~m}$ (NH03-NH12), the kindergarten house an average of $8 \mathrm{~m}$ in height, designated as NH01-NH02 (Fig. 1). The total surface area of the residential buildings (vertical walls and roofs) is 55,965.09 $\mathrm{m}^{2}$ (5.6 ha) and the non-residential buildings is $7,080.90 \mathrm{~m}^{2}(0.71$ ha), together $63,045.99 \mathrm{~m}^{2}(6.3 \mathrm{ha})$. Add to them the horizontal paved areas of roads and parking lots, the total area of biologically inactive surfaces is $77,805.45 \mathrm{~m}^{2}(7.71 \mathrm{ha})$. These areas represent a negative component of the solar thermal balance and enhance the heat island effect in the housing estate. Biologically active horizontal areas of green cover a total of $37804.17 \mathrm{~m}^{2}(3.71$ ha), which is only $32.70 \%$ compared to all biologically inactive surfaces $(67.30 \%)$.

In the field investigation, we have found that many hard and biologically inactive areas are covered by a horizontal projection of tree crowns. We evaluated these as shaded areas, which relatively reduce the share of inactive areas and mitigate heat island values (Table 2). Residential buildings, due to their height above $20 \mathrm{~m}$, do not have real shaded roofs, because the height of trees reaches a maximum of 10-16 m, in some cases up to $22 \mathrm{~m}$ (e.g., Acer saccharinum, Platanus $x$ acerifolia). The category of nonresidential houses has only sporadic tree crown cover of horizontal roof area through the treetops. The highest share of tree crown cover is achieved by horizontal areas of inter-block green areas $(25.97 \%)$ and residential front gardens $(22.36 \%)$. The total proportion of tree crown covered areas reach $20.82 \%$ in relation to all horizontal areas (Table 2). The side shade of tall trees is also significant, which is variable during the day, but important both for the walls of residential buildings and the paved horizontal areas, especially playgrounds and parking lots. Trees near residential houses also create a side shade even for 3 to 5 floor apartments. These trees also have an important effect of close visual perception contact of the inhabitants from their apartments with emphasis on tree crown structure and possible nesting birds, as natural and aesthetic elements. Shaded areas by trees, whether permanent or daytime change, have a significant cooling effect and contribute to a more favourable microclimate in the housing estate spaces. Biologically active areas in the housing estate are reinforced by the formation of shrubs, which were surveyed as undergrowth groups, at the edges of tree compositions, but mainly in the front gardens. Here, they formed individual, group and ground cover composition, or clipped hedges. These are in the lining function to the residential building entrances or to enhance aesthetic image. In the evaluated area of the housing estate, the stands of shrubs form a total of $420 \mathrm{~m}^{2}$ and are of a significant spatial, biological and aesthetic contribution to the residential complex.

From the measured land-use dates in land-cover category, we have defined the relative indices. These express the relative degree of natural value and the resulting potential of biodiversity, the cooling effect and the suitability of green spaces for recrea- 
Table 3. Correlations between tree height, stem girth, crown width and tree vitality parameter in deciduous trees.

\begin{tabular}{|l|c|c|c|c|}
\hline \multicolumn{5}{|c|}{$\begin{array}{c}\text { Kendall Tau b Correlation Coefficients, } \mathbf{N}=138 \\
\text { Prob }>\mid \text { tau| under H0: Tau = }\end{array}$} \\
\hline \multirow{2}{*}{ Tree height } & Tree height & Stem girth & Crown width & Tree vitality parameter \\
\hline \multirow{2}{*}{ Stem girth } & 1.00000 & 0.54144 & 0.39583 & 0.09436 \\
& & $<0.0001^{* * *}$ & $<0.0001^{* * *}$ & 0.1782 \\
\hline \multirow{2}{*}{ Crown width } & 0.54144 & 1.00000 & 0.55256 & 0.24888 \\
& $<0.0001$ & 0.55256 & $<0.0001^{* * *}$ & $0.0002^{* * *}$ \\
\multirow{2}{*}{ Tree vitality parameter } & 0.39583 & $<0.0001$ & 1.00000 & 0.38694 \\
& $<0.0001$ & 0.24888 & 0.38694 & $<0.0001^{* * *}$ \\
\hline
\end{tabular}

Notes: ${ }^{\star \star \star} \mathrm{P}<0.001 ;{ }^{\star \star} \mathrm{P}<0.01 ;{ }^{\star} \mathrm{P}<0.05$.

Table 4. Correlations between tree height, stem girth, crown width and tree vitality parameter in coniferous trees.

\begin{tabular}{|l|c|c|c|c|}
\hline \multicolumn{5}{|c|}{$\begin{array}{c}\text { Kendall Tau b Correlation Coefficients, } \mathbf{N}=\mathbf{5 7} \\
\text { Prob }>\mid \text { tau| under H0: Tau = 0 }\end{array}$} \\
\hline \multirow{2}{*}{ Tree height } & Tree height & Stem girth & Crown width & Tree vitality parameter \\
& 1.00000 & 0.58376 & 0.51059 & 0.02151 \\
\multirow{2}{*}{ Stem girth } & 0.58376 & $<0.0001^{\star * *}$ & $<0.0001^{\star * *}$ & 0.8439 \\
\hline \multirow{2}{*}{ Crown width } & $<0.0001$ & 1.00000 & 0.53293 & -0.00954 \\
& 0.51059 & 0.53293 & $<0.0001^{\star * *}$ & 0.9280 \\
\hline \multirow{2}{*}{ Tree vitality parameter } & $<0.0001$ & $<0.0001$ & 1.00000 & 0.36260 \\
& 0.02151 & -0.00954 & 0.36260 & $0.0016^{\star *}$ \\
\hline
\end{tabular}

Notes: ${ }^{* *} \mathrm{P}<0.001 ;{ }^{* *} \mathrm{P}<0.01 ;{ }^{*} \mathrm{P}<0.05$.

tion and well-being of inhabitants. The calculated indices are as follows:

(a) Proportional green area index (PGAI); share of green area cover (GAC) to built-up area cover (BAC) PGAI $=37,804.17 \mathrm{~m}^{2}(\mathrm{GAC}) \div 26,595.93 \mathrm{~m}^{2}($ BAC $)=1.42$

(b) Effective green area index (EGAI); share of green area cover (GAC) to all biologically inactive surfaces (BISC) EGAI $=37,804.17 \mathrm{~m}^{2}(\mathrm{GAC}) \div 77,805.45 \mathrm{~m}^{2}($ BISC) $=0.49$

(c) Tree shade index (TSI); share of tree crown area cover (TAC) to all horizontal area with tree crown cover share (HAC): TSI $=11,523.78 \mathrm{~m}^{2}(\mathrm{TAC}) \div 55,336.95 \mathrm{~m}^{2}(\mathrm{HAC})=0.21$

(d) Anthropisation level of woody plant species (ALPS); share of alien woody plant species (APS) to all woody plant species (TPS): ALPS $=45($ APS $) \div 67$ (TPS) $=0.67$.

We consider the ratio of green areas to built-up and paved areas (PGAI index) to be balanced, given the average height of residential buildings, but also the current tendency to increase the density of housing estates by other block houses. In terms of microclimate of the assessed housing estate, we evaluate the effective green area index (EGAI) as significant because it expresses complex spatial parameters affecting the quality of the residential environment. No vertical green walls or roof gardens on the buildings were identified in the area of the studied housing estate, which would significantly contribute to climate comfort and increase the EGAI index values. The tree shade index (TSI) is relatively low $(0.21)$, which is also caused by many individuals of young trees with a small crown. We consider as the optimal value 0.5 to 0.6 , which can be achieved by increasing the proportion of trees, especially in large open areas. In assessing tree vitality, two characteristic features of the tree crown were assessed, namely the size and degree of foliage. We consider these characteristics to be important indicators of the quality of parkland on which the value level of all categories of ecosystem services in residential areas of urban settlements depends. The tree vitality class (TVC) is most often 4 , the second place is 5 , less often there are trees with TVC equal to 3 . The data show that the vitality of the trees is dependent on the age of the tree, the density of the tree canopy, and on the tree as a compositional element, for example, solitaire, group, alley, park (forest park). The density of $0.5-0.7$ is optimal for designing the spatial structure of park tree stands, which allows favourable growth and development of larger compact tree crowns with a high proportion of leaf biomass. In terms of age structure, we functionally evaluate trees over 40 years of age, which already represent the stage of maturity with a growth height over $10 \mathrm{~m}$. Trees of this growth stage have been dominantly represented in the assessed housing estate built since 1970, due to the period of construction of the housing estate. Some groups with a higher degree of density were 
Ekológia (Bratislava) 2021: 40(1): 80-90

Table 5. Correlations between tree height, stem girth, crown width and tree vitality parameter in deciduous trees of genus Tilia sp.

\begin{tabular}{|l|c|c|c|c|}
\hline \multicolumn{5}{|c|}{$\begin{array}{c}\text { Kendall Tau b Correlation Coefficients, } \mathbf{N}=\mathbf{5 1} \\
\text { Prob }>\mid \text { tau| under H0: Tau= }\end{array}$} \\
\hline \multirow{2}{*}{ Height of tree } & Height of tree & Stem girth & Crown width & Tree vitality parameter \\
\hline \multirow{2}{*}{ Stem girth } & 1.00000 & 0.69551 & 0.57112 & 0.36814 \\
& 0.69551 & $<0.0001^{* * *}$ & $<0.0001^{* * *}$ & $0.0017^{* *}$ \\
\hline \multirow{2}{*}{ Crown width } & $<0.0001$ & 1.00000 & 0.63482 & 0.33662 \\
& 0.57112 & 0.63482 & $<0.0001^{\star * *}$ & $0.0031^{* *}$ \\
\hline \multirow{2}{*}{ Tree vitality parameter } & $<0.0001$ & $<0.0001$ & 1.00000 & 0.35275 \\
& 0.36814 & 0.33662 & 0.35275 & $0.0039^{* *}$ \\
\hline
\end{tabular}

Notes: ${ }^{* *} \mathrm{P}<0.001 ;{ }^{* *} \mathrm{P}<0.01 ;{ }^{*} \mathrm{P}<0.05$.

Table 6. The influence of the tree vitality parameter to the measured traits variance.

\begin{tabular}{|c|c|c|c|}
\hline \multirow[t]{2}{*}{ Statistical limit } & \multirow[t]{2}{*}{ Trait } & \multicolumn{2}{|c|}{ Type of trees } \\
\hline & & coniferous & deciduous \\
\hline & & \multicolumn{2}{|c|}{ Kruskal-Wallis Test } \\
\hline Chi-Square & Height of tree & 0.2103 & 2.2555 \\
\hline Pr $>$ Chi-Square & Height of tree & 0.9002 & 0.3238 \\
\hline Chi-Square & Stem girth & 0.1583 & 13.4286 \\
\hline $\operatorname{Pr}>$ Chi-Square & Stem girth & 0.9239 & $0.0012^{\star *}$ \\
\hline Chi-Square & Crown width & 9.9791 & 28.7547 \\
\hline $\operatorname{Pr}>$ Chi-Square & Crown width & $0.0068^{\star \star}$ & $<0.0001^{\star * *}$ \\
\hline \multicolumn{4}{|c|}{ Median One-Way Analysi } \\
\hline Chi-Square & Height of tree & 0.4388 & 0.2891 \\
\hline $\operatorname{Pr}>$ Chi-Square & Height of tree & 0.8030 & 0.8654 \\
\hline Chi-Square & Stem girth & 0.4309 & 10.9980 \\
\hline $\operatorname{Pr}>$ Chi-Square & Stem girth & 0.8062 & $0.0041^{\star \star}$ \\
\hline Chi-Square & Crown width & 8.1144 & 24.8191 \\
\hline Pr $>$ Chi-Square & Crown width & $0.0173^{*}$ & $<0.0001^{*}$ \\
\hline
\end{tabular}

Notes: ${ }^{* *} \mathrm{P}<0.001 ;{ }^{* \star} \mathrm{P}<0.01 ;{ }^{*} \mathrm{P}<0.05$.

reflected in the reduction of crown size and foliage density, but also in the crown shape deformation. Such a state is the result of species and interspecies competition, but also differences in solar energy intake.

In total, 293 trees were identified in the studied housing estate, which is a relatively balanced state in the area of 3.78 ha of green space. Many individuals, however, are in younger growth stage, planted later. We consider 100 mature trees per 1 ha of park area to be optimal. In terms of species diversity of trees, 36 species of deciduous trees were identified, 17 of them native and 19 alien species. A total of 11 species were identified in the conifer category, only 3 native and 8 alien species. In the group of shrubs, 20 species were identified, of which only 2 are native and 18 are alien. In terms of abundance, the group of deciduous trees is dominated by native species of the genus Acer sp., Tilia sp., Fraxinus sp., Carpinus sp., and Sorbus sp. Among the alien species, Tilia tomentosa, Acer saccharinum, Platanus $x$ acerifolia, Elaeagnus angustifolia and Celtis occidentalis prevail; in order from predominant to complementary. The applied species show a high degree of resilience and suitability for the given environmental conditions. In coniferous trees, the occurrence of which is only about $25 \%$ compared to deciduous species, only three species - Pinus sylvestris (highest share), Picea abies and Abies alba (lowest share) - are native. Almost $75 \%$ of the coniferous species are alien, with a prevalence of Pinus nigra, Picea pungens, Pseudotsuga menziesii and Picea omorica (from highest to lowest share). All are resilient in their environment, show high growth vitality and aesthetically enrich the green spaces. Two species - Robinia pseudoacacia and Amorpha fruticosa have been identified in the invasive biological manifestation category, and only in a low occurrence, which we consider as a positive phenomenon. The anthropisation index of woody plant species is relatively high (ALPS $=0.67$ ), due to the high proportion of alien species in the shrubby growth category.

\section{Statistical assessment}

In the evaluation of tree vitality class (TVC), the results were almost similar in deciduous and coniferous tree species. Tree vitality classes 5, 4, 3 were predominantly identified, but for decidu- 
Fit Plot for Crown width

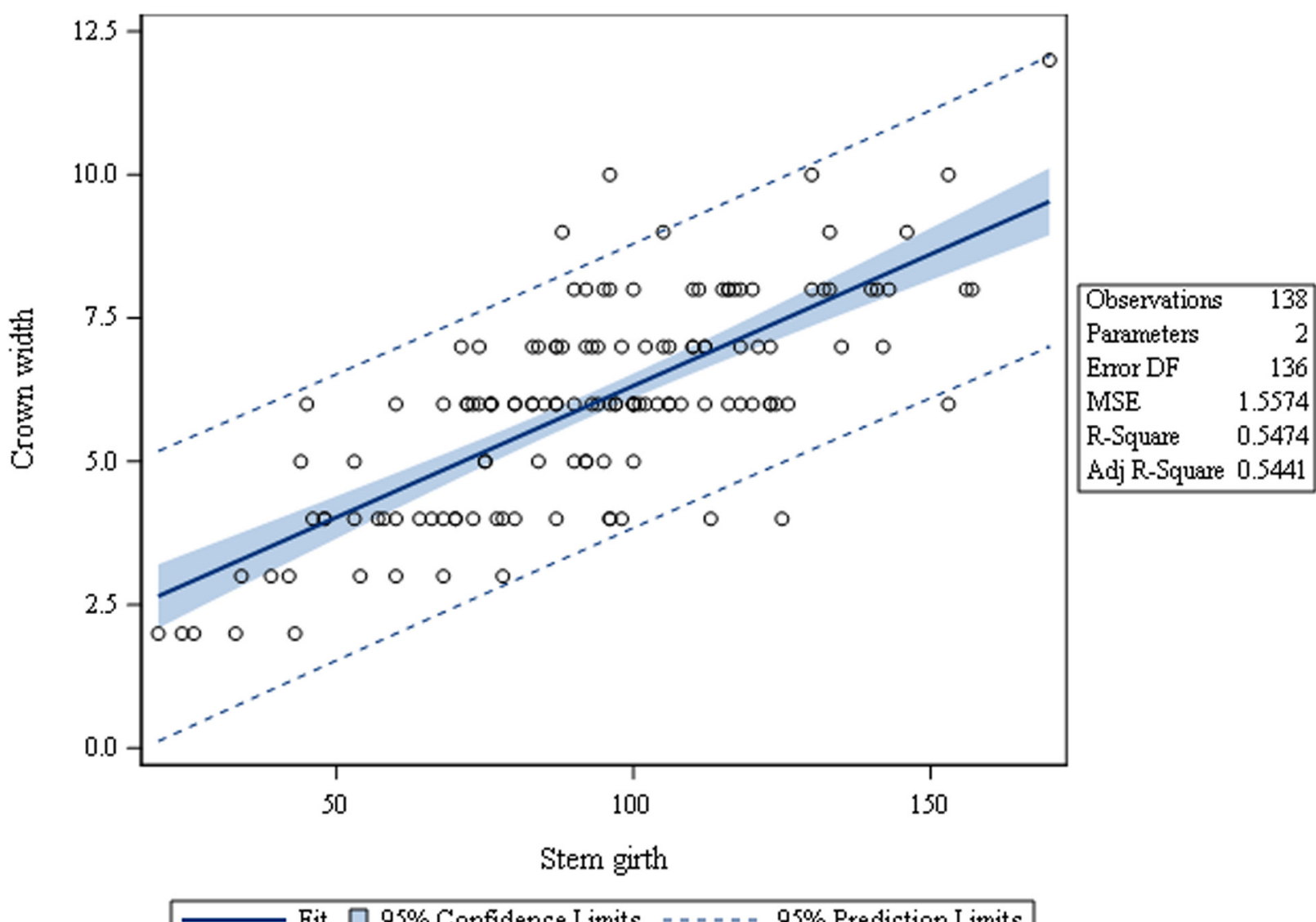

Fit $\square 95 \%$ Confidence Limits - - - - 95\% Prediction Limits

Fig. 3. Linear dependency of the crown width on stem girth. Linear regression formula: Crown width $=1.733+0.046$ stem girth.

ous species also, class 2 represents a negligible share of only $1.8 \%$. The following classes have been identified in the evaluated classes: tree vitality class - deciduous trees/coniferous, in percentage assessed trees: 5 - 49.10/45.07; 4 - 35.14/35.21; 3 - $13.96 \% / 19.72 \%$. In the group of deciduous trees, a correlation analysis of evaluated traits was performed only for 7 tree species with a number over 10 individuals, altogether 138 individuals for all the evaluated trees (Table 3 ). The tree vitality parameter has the highest correlation with crown width and stem girth. All the correlations were significant except for the correlation between tree vitality parameter and tree height. In the group of coniferous trees, 4 species were evaluated, in total 57 trees. For this group of trees, the correlation was similar to that of the deciduous species, but the tree vitality had a significant correlation only with crown width (Table 4). Considering the almost identical tree habit of the genus Tilia sp., where the highest number of 51 individuals was evaluated, we analysed the linear correlations between the evaluated tree characteristics (Table 5). Relationships between traits were low and moderate but all were significant.

Statistical differences between tree vitality parameters in measured traits were found by non-parametric analysis of variance (Kruskal-Wallis test and median one-way analysis test)
(Table 6). The results show a statistically significant difference between the tree vitality parameter and crown width at coniferous trees. In the group of deciduous trees, there is a statistically significant difference between the classes of tree vitality parameter in crown width and stem girth. The same result was achieved in the median test for both groups of tree species. The linear relationship was determined between crown width and stem girth in deciduous trees. Using linear regression analysis, the parameters of regression function were estimated (1.733 and 0.046 ) with a reliability of 0.547 (Fig. 3).

The results of the statistical evaluation of the quantitative and qualitative traits of trees in the green areas of the Klokočina housing estate confirm the relevant level of their mutual relations and the degree of statistical significance.

\section{Discussion}

The effectiveness of the ecosystem services of green spaces in the city depends mainly on the proportion of green areas to the total area of the city. Some European cities report the following green area values, for example, Amsterdam and Barcelona less than $10 \%$, Budapest $20 \%$, Vienna 25\%, Zurich $30 \%$, Bratislava 40\% (Rehačková, Pauditšová, 2006), Warsaw 41.7\% (Szulcze- 
wska et al., 2014), Strasbourg $27.8 \%$ (Selmi et al., 2016). The city of Nitra represents almost $27 \%$ of all green areas. The $50 \%$ share of green areas in the city is often considered to be the optimal proportion (Supuka, 2008; Gupta et al., 2012). For 299 European cities, the availability of green areas with a minimum size of 2 hectares has been processed up to 300-500 $\mathrm{m}$. Of these, 20 ranked for the top value, including Banská Bystrica and Karlovy Vary (Kabisch et al., 2016). The city of Nitra has two important public parks namely Sihot and Borina, the second one is now also accessible for the assessed estate Klokočina within a distance of 500 to $1000 \mathrm{~m}$. The total area of greenery on the assessed segment of the Klokočina housing estate represents 3.781 ha, but the current buildings divide it into smaller areas with an area of 0.3 to 0.5 ha. These provide recreational space and daily visual contact for residents of each apartment building. They are also complementary to the nearest large park Borina near Klokočina. In the city of Oslo, Norway, 74 small parks and fragments of greenery with an area of up to 0.3 ha have been investigated, called urban small pocket parks (Nordh, Østby, 2013). It describes their importance for people not only as an element of nature for daily contact with psychological, recreational, but also for microclimatic effect. Such small parks have been defined as complementary to large urban parks, which also serve as connectivity to the urban green system. In the green areas of the city, great emphasis is placed on reducing the proportion of impervious surfaces, especially car parks, their reconstructions to semi permeable and grassed, respectively (Nowak, Greenfield, 2012). In the assessed Klokočina housing estate, car parks make up a high proportion, almost 1.1 ha, which are potential areas for their unsealing, grass-paving and increasing thereby the proportion of green areas. Tree cover is one of the most important factors of quality and effective level of ecosystem services of greenery, especially climate and biodiversity in the city. In the green areas of Atlanta, USA, the tree cover was identified on average as $51.2 \%$, and in Detroit as $32.3 \%$ in 2010 (Merry et al., 2014). The minimum tree cover was defined as $40 \%$, the optimal $50-60 \%$, and a share of less than $40 \%$ was considered deficient (Nowak, Greenfield, 2012). In our case, in the assessed housing estate Klokočina, the tree cover reaches $20.82 \%$. Recently, many published studies have been devoted to the comparison of biotical active and inactive (paved) areas in the urban structure of the city or in green spaces. From these, the relative indices are calculated. These include features of health effect of the green areas, residential quality of the city, quality of ecosystem services of green spaces, respectively. Anguluri and Narayanan (2017) published the normalized differential vegetation index (NDVI) as a proportion of green areas around the city at a distance of 500 to $1000 \mathrm{~m}$; green index (GI) as the ratio of the green area to the total area of the assessed area; proportional green index (PGI) as a proportion of all green areas to the population in the city's ward. In this study, we evaluated the proportional green area index (PGAI) as the proportion of green areas to the builtup areas of the assessed settlement; effective green area index (EGAI) as the ratio of all green areas to all biologically inactive surfaces. We have applied the shade tree factor similar to that used by McPherson et al. (2018). The content of all variables used is to obtain information on the proportion of green areas to built-up areas or per 1 inhabitant of the city. Other indices may be targeted, for example, to assess the biodiversity or resi- dential quality of the city. The species composition of trees and herbs in green spaces contribute to the biodiversity level, the resilience of green areas, but also the aesthetic variability and value of the city. There are 18 tree species on average in North Europe states, 21 in Central Europe and 34 in South Europe (Saebo et al., 2005). In China, 257 cites were evaluated and a total of 1,671 tree species and cultivars, 743 shrub and 226 liana species were identified; in the United Kingdom 1,360 and in the United States 124 tree species were identified (Yan, Yang, 2017). In our study, we identified 47 species of trees and 20 species of bushes in a small segment of the Klokočina housing estate. In tree species, in terms of abundance, natural species dominate, which enhances the natural character of the green areas in the housing estate. In our study, we have in many cases identified the comparable traits of green areas with other authors. Some were clearly different, reflecting the different conditions of the assessed green spaces.

\section{Conclusion}

Housing estates are typical residential complexes of collective housing not only in Slovakia, but also throughout Europe and the world. The dwelling quality in housing estates depends on the quality of housing stock and the quality of green spaces. The beginnings of the construction of housing estates in Slovakia date back to the period after World War II. Currently, the situation is stabilised due to a relatively good availability of apartments. Green spaces in housing estates are still satisfactory up to now. Initially, young tree stands had reached larger spatial dimensions for more than 40 years since planting and are now fully functional. The quality of greenery of housing estates has an average value. Species composition of trees corresponds to environmental conditions. The mixture of natural and alien tree species increases the compositional diversity of green areas; however, the abundance of natural tree species is predominant, which determines the natural character of greenery areas in housing estates. Invasive tree species have a low share. In the process of green space restoration, mainly playgrounds were added and the share of open spaces for public road networks increased. The results of the study conducted in the Klokočina housing estate shows the need to increase the care for vegetation elements, increase the proportion of trees in the compositions, and reconstruct the parking lots into the grass-paved areas. A potential for the future consists also in the creation of roof gardens and green walls. Due to a general drying of the environment, it would be necessary to establish more close-to-nature grasslands and flower beds in the housing estate with a prevalence of xerophytic species of herbaceous perennials and grasses. There is also a potential in the creation of rain gardens to increase climate comfort and biodiversity in the housing estate. We propose partial changes in the front garden segment at the entrance to residential buildings. Remove hedges and add flowering shrubs in medium high to the space. Also, apply the composition of shrubs in compact and low ground cover formations. To increase the aesthetic effect, we suggest the creation of perennial flower beds. Green spaces fulfil important climatic, recreational, aesthetic and social ecosystem services for inhabitants of the Klokočina housing estate. They are an important component of the green infrastructure of the Nitra city. 


\section{Acknowledgements}

This study was elaborated thanks to the support by the project VEGA 1/0044/17 and projects KEGA 046SPU-4/2018, KEGA 011SPU-4/2019 and KEGA 003SPU-4/2020. The authors express their gratitude to Dr. Eva Strapáková for the statistical processing of the results.

\section{References}

Anguluri, R. \& Narayanan P. (2017). Role of green space in urban planning Outlook towards smart cities. Urban Forestry and Urban Greenning, 25, 58- 65. DOI: 10.1016/j.ufug.2017.04.007.

Bihuňová, M., Halajová, D., Tóth, A. \& Štrba P. (2017). Assessment of green infrastructure in the cadastral area of Šala. Journal of Landscape Management, 8(1), 58-74

Bowler, D.F., Buyung-Ali, J., Knight, T.M. \& Pullin A.S. (2010). Urban greening to cool towns and cities: a systematic review of the empirical evidence. Landsc. Urban Plann., 97, 147-155. DOI: 10.1016/j.landurbplan.2010.05.006.

Chen, H., Gu, I., Li, J. \& Ge C. (2009). Analysis on relations between the pattern of urban forests and heat Island effect in Chengoen. Acta Ecologica Sinica, 29, 4865-4874.

Eliasson, I. \& Upmanis H. (2000). Nocturnal airflow from urban parks implications for city ventilation. Theor. Appl. Clim., 66(1-2), 95-107. DOI 10.1007/s007040070035.

Goddard, M.A., Dougill, A. \& Benton T.G. (2010). Scaling up from gardens Biodiversity conservation in urban environments. Trends Ecol. Evol. 25(2), 90-98.DOI: 10.1016/j.tree.2009.07.016.

Gupta, K., Kumar, P., Pathan, S.K. \& Sharma K.P. (2012). Urban neighbourhood green index- A measure of green spaces in urban areas. Landsc. Urban Plann., 105, 325-335. DOI: 10.1016/j.landurbplan.2012.01.003.

Hrubík, P., Kollár, J., Rovná, K., Tkáčová, S. \& Mňahončáková E. (2011). Qualitative survey, klassification and evaluation of the healthy condition of woody plants for the purpose of garden-architectonical and landscape creation (in Slovak). Nitra: SPU.

Jaganmohan, M., Knapp, S., Buchmann, C.M. \& Schwarz N. (2016). The bigger, the better? The influence of urban green space, design on cooling effects for residential areas. J. Environ. Qual., 45, 134-145. DOI: 10.2134/ jeq2015.01.0062.

Jayasooriya, V.M., Ng, A.W.M., Muthukumaran, S. \& Perera B.J.C. (2017) Green in frastructure practices for improvement of urban air quality. Urban Forestry and Urban Greening, 21, 34-47. DOI: 10.1016/j. ufug.2016.11.007.

Juhola, S. (2018). Planning for a green city: The green factor tool. Urban Forestry and Urban Greening, 34, 254-258. DOI: 10.1016/j.ufug.2018.07.019.

Kabisch, N., Strohbach, M., Haase, D. \& Kronenberg J. (2016). Urban green space availability in European cities. Ecological Indicators, 70, 586-596. DOI: 10.1016/j.ecolind.2016.02.029.

Klein, J. \& Rózová Z. (2017). Methods of trees evaluation with the site-specific for microclimate in urban environment: the case of study Nitra (Slovakia). Ekológia (Bratislava), 36(1), 40-51. DOI: 10.1515./eko-2017-0004

Kong, F., Yin, H., James, P., Hutyra, L.R. \& He H.S. (2014). Effects of spatial pattern of greenspace on urban cooling in a large metropolitan area of eastern China. Landsc. Urban Plann., 128, 35-47. DOI: 10.1016/j.landurbplan.2014.04.018.

Lee, H., Mayer, H. \& Chen L. (2016). Contribution of trees and grasslands to the mitigation of human heat stress in a residential district of Freiburg, Southwest Germany. Landsc. Urban Plann., 148, 37-50. DOI: 10.1016/j. landurbplan.2015.12.004.

Majkowska, A., Kolendowicz, I., Pólrolniczak, M., Hauke, J. \& Czarnecki B. (2017). The urban heat island in the city of Pozñan as derived from Landsat 5 TM. Theor. Appl. Clim., 128, 769-783. DOI: 10.1007/s00704016-1737-6.

Martin, P., Baudonin, J. \& Gachon P. (2015). An alternative method to characterize the surface urban heat island. Int. J. Biometeorol., 59(7), 849-861. DOI: 10.1007/s00484-014-0902-9.

McHale, M., Burke, I., Lefsky, M., Peper, P. \& McPherson E. (2009). Urban forest biomass estimates. Is it important to use allometric relationships developed specifically for urban trees? Urban Ecosystems, 12, 95-113. DOI: 10.1007/s11252-009-0081-3.
McPherson, E.G., Xiao, Q., van Doorn, N.S., Johnson, N., Albert, S. \& Peper P.J. (2018). Shade factors for 149 taxa of in - leaf urban trees in the USA. Urban Forestry and Urban Greening, 31, 204-211. DOI: 10.1016/j. ufug.2018.03.001.

Merry, K., Syri, J., Bettinger, P. \& Bowker J.M. (2014). Urban tree cover change in Detroit and Atlanta, USA, 1951-2010. Cities, 41, 123-131. DOI 10.1016/j.cities.2014.06.012.

Niemelä, J. (2014). Ecology of urban greenspaces: The way forward in answering major research questions. Landsc. Urban Plann., 125, 298-303. DOI 10.1016/j.landurbplan.2013.07.014.

Nordh, H. \& Østby K. (2013). Pocket parks for people- A study of park design and use. Urban Forestry and Urban Greenning, 12, 12-17. DOI: 10.1016/j. ufug.2012.11.003.

Nowak, D.J., Grane, D.F. \& Stevens J.C. (2006). Air pollution removal by urban trees and shrubs in the United States. Urban Forestry and Urban Greening, 4(3-4), 115-123. DOI: 10.1016/j.ufug.2006.01.007.

Nowak, D.J. \& Greenfield E.J. (2012). Tree and impervious cover in the United States. Landsc. Urban Plann., 107, 21-30. DOI: 10.1016/j.landurbplan.2012.04.005.

Nowak, D.J., Greenfield, E.J., Hoehn, R.E. \& Lapoint E. (2013). Carbon storage and sequestration by trees in urban and community areas of the United States. Environ. Pollut., 178, 229-230. DOI: 10.1016/j.envpol.2013.03.019.

Nowak, D.J., Hirabayashi, S., Doyle, M., McGovern, M. \& Paster J. (2018) Air pollution removal by urban forests in Canada and its effect on air quality. Urban Forestry and Urban Greening, 29, 40-48. DOI: 10.1016/j. ufug.2017.10.019.

Papangelis, G., Tombron, M., Dandon, A. \& Kontos T. (2012). An urban “Green planning" approach utilizing the weather research and forecasting (WRF) modelling system. A case study of Athens, Greece. Landsc. Urban Plann., 105, 174-183. DOI: 10.1016/j.landurbplan.2011.12.014.

Reháčková, T. \& Pauditšová E. (2006). Vegetation in urban environment (in Slovak). Bratislava: Cicero, s.r.o.

SAS Institute Inc. (2008). SAS/ Enterprise Guide 7.1. Cary. NC: SAS Institute Inc.

Saebo, A., Borzan, Z., Ducatilion, C., Hatizstathis, A., Lagerstrom, T., Supuka, J., Garcia-Valdecantos, J.L., Reg, F. \& Van Styken J. (2005). The selection of plant materials for street trees, park trees and urban woodland. In C. Konijnendijk, K. Nilsson, T. Randrup \& J. Shipperijn (Eds.), Urban forest and trees: a reference book (pp. 257-280). Berlin, Heidelberg: Springer Verlag.

Selmi, W., Weber, Ch., Riviere, E., Blond, N., Mehdi, L. \& Nowak D. (2016): Air pollution removal by trees in public green spaces in Strasbourg city, France. Urban Forestry and Urban Greening, 20, 40-48. DOI: 10.1016/ ufug.2016.04.010.

Shackleton, S., Chinyimba, A., Hebinck, P., Shackleton, Ch. \& Kaoma H. (2015). Multiple benefits and values of trees in urban landscape in two towns in northern South Africa. Landsc. Urban Plann., 136, 76-86. DOI 10.1016/j.landurbplan.2014.12.004.

Supuka, J. (1996). Settlement environment conditions and evaluation of their impact on urban vegetation. Ekológia (Bratislava), 15, 37-46.

Supuka, J. (2008). The new trends in nature park design and cological networks in towns (in Slovak). In J. Supuka \& L. Feriancová (Eds.), Vegetation structure in settlments. Parks and gardens (pp. 81-100). Nitra: SPU.

Supuka, J., Šinka, K., Pucherová, Z., Verešová, M., Feriancová, L., Bihuňová M. \& Kuczman G. (2013). Landscape structure and biodiversity of woody plants in the agriculture landscape. Folia Universitatis Agriculturae et Silviculturae Mendelianae Brunensis, 6(9), 187.

Supuka, J., Šinka, K., Kuczman, G. \& Billiková M. (2019). Vegetation structures of the city and their use for recreation activities. In J. Fialová (Ed.) Public recreation and landscape protection - with sense hand in hand (pp. 466-472). Brno: Mendel University in Brno.

Szulczewska, B., Giedych, R., Borowski, J., Kuchcik, M., Sikorski, P., Mazurkiewicz, A. \& Stanczyk T. (2014). How much green is needed for a vital neighbourhood? In search for empirical evidence. Land Use Policy, 38, 330-345. DOI: 10.1016/j.landusepol.2013.11.006.

Taylor, L. \& Hochuli D.F. (2017). Defining greenspace: multiple uses across multiple disciplines. Landsc. Urban Plann., 158, 25-38. DOI: 10.1016/j. landurbplan.2016.09.024.

Tian, J., Jim, C. J. \& Wang H. (2014). Assessing the landscape and ecological quality of urban green spaces in the compact city. Landsc. Urban Plann., 121, 97-108. DOI: 10.1016/j.landurbplan.2013.10.001. 
Timilsina, N., Standhammer, Ch., Escobedo, F.J. \& Lawrence A. (2014). Free biomass, wood waste field, and carbon storage changes in an urban forest. Landsc. Urban Plann., 127, 18-27. DOI: 10.1016/j.landurbplan.2014.04.003

Tóth, A. \& Timpe A. (2017). Exploring urban agriculture as a component of multifunctional green infrastructure: Application of figure-ground plans as a spatial analysis tool. Moravian Geographical Reports, 25(3), 208-218. DOI: 10.1515/mgr-2017-0018.

Uhrin, P. \& Supuka J. (2016). Quality assessment of urban trees using growth visual and chlorophyll fluorescence indicators. Ekológia (Bratislava), 35, 160-172. DOI: 10.1515/eko-2016-0013.

Uhrin, P., Supuka, J. \& Billiková M. (2018). Growth adaptability of Norway maple (Acer platanoides, L.) to urban environment. Folia Oecologica, 45(1), 33-45. DOI: 10.2478/foecol-2018-0004.

Vaculová, V. \& Štěpánková R. (2017). Application of rain gardens to an urban - housing estate in Nitra, Slovakia. Acta Horticulturae et Regiotecturae, 20, 1-5. DOI: 10.1515/ahr-2017-0001.
Vallecillo, S., Polce, Ch., Barbosa, A., Castillo, C.P., Vandecasteele, J., Rusch G.M. \& Maes J. (2018). Spatial alternatives for green infrastructure planning across the EU: An ecosystem service perspective. Landsc. Urban Plann., 174, 41-54. DOI: 10.1016/j.landurbplan.2018.03.001.

Yan, P. \& Yang J. (2017). Species diversity of urban forests in China. Urban Forestry and Urban Greening, 28, 160-166. DOI: 10.1016/j. ufug.2017.09.005.

Yang, L., Quin, F., Song, D.X. \& Zheng K.J. (2016). Research on urban heatisland effect. Procedia Engineering, 169, 11-18. DOI: 10.1016/j.proeng.2016.10.002.

Yong, R.F. (2010). Managing municipal green space for ecosystem services. Urban Forestry and Urban Greening, 9, 313-321. DOI: 10.1016./j. ufug.2010.06.007.

Yu, Z., Guo, X., Zeng, Y., Koga, M. \& Vejre H. (2018). Variations in land surface temperature and cooling efficiency of green space in rapid urbanization: The case of Fuzhon city, China. Urban Forestry and Urban Greening, 29, 113-121. DOI: 10.1016./j.ufug.2017.11.008. 